\title{
UK blood screening begins
}

\section{London}

LARGE-scale testing of UK blood samples for the presence of human immunodeficiency virus (HIV) will begin in January. The samples will have been taken for reasons other than HIV testing and will, says the Department of Health, be "anonymised", so that it will be impossible to trace a positive result back to an individual. But, because information about the testing will be made available, there is a danger that those most at risk will be under-represented.

There will be a number of different studies. Of the first two to be set in motion, one will survey blood taken during pregnancy at antenatal clinics and the other will use samples from sexually transmitted disease clinics. Later in 1990, tests will start on blood from certain categories of patients at some general hospitals and on blood of newborn infants, in the form of the dried spots of blood on Guthrie cards used for phenylketonuria screening.

The basis for the programme of anonymous testing is laid out in the 25 November British Medical Journal by O. N. Gill of the Public Health Laboratory Service AIDS Centre and two colleagues. If specific consent has to be sought, as when the donors of samples are identified, high-risk individuals are much more likely to decline than those at low risk, they say. Anonymous testing can avoid that bias as it does not necessarily require consent. has decided that patients will be told about the surveys by means of leaflets and posters. Precisely how that is put into effect has not been decided and may be left to local authorities. The extent to which this will re-introduce the bias associated with systems of consent is a matter of concern to some observers.
Nonetheless, the Department of Health

To maintain the anonymity of the blood samples, only limited information will be attached to them. At a minimum, this will be the sex, age and broad geographical location of the person from whom the sample was drawn. Samples from sexually transmitted disease clinics should also carry with them information on the donor's sexual orientation, broad clinical diagnosis and intravenous drug use, say the authors of the BMJ article, but whether that will be available without consent has yet to be determined. "The surveys are an important step forward" says Professor Roy Anderson of Imperial College, a leading advocate of anonymous testing, "but only a beginning". The best source of information would be cohort studies without consent in sexually transmitted disease clinics, he said.

The programme of testing announced last week follows a decision in favour of anonymous tests made just over a year ago by the UK government, despite some residual opposition. The Medical Research Council was charged with designing the surveys. Their results will be coordinated by the Public Health Laboratory Service AIDS Centre and the Department of Genito-urinary Medicine of University College and Middlesex School of Medicine. Several hundreds of thousands of samples are to be tested over the next few years.

Peter Newmark - A concerted campaign to persuade the UK government to compensate the 1,200 UK haemophiliacs who became infected with HIV through contaminated blood products has achieved a measure of success. While denying liability, the UK government last week announced a donation of $£ 19$ million to the Macfarlane Trust which will administer the handout.

Two years ago the government gave $£ 10$ million to the same trust.

\section{DAHLEM CONFERENCES}

\section{Last-minute reprieve}

\section{Munlch}

ENDANGERED in June by the withdrawal of a long-time sponsor, the worldrenowned Dahlem Conferences have been rescued by the Free University of (West) Berlin. There will be no interruption of the conferences, which have been held four times a year for the past 15 years.

When the previous sponsor, the 'Donors Association for Promoting Arts and Sciences in West Germany' (Stifterverband für die Deutsche Wissenschaft or $\mathrm{SV})$ withdrew its support earlier this year, an alarm went out in the international research community that may have helped to save the conferences (see Nature 340, $86 ; 1989)$. More than 150 letters poured in to the governing mayor and the Senate of West Berlin in support of the conferences.

The new arrangement with the Free University will ensure the conferences' future for at least four years. The arrangement meets all the conditions set by the conferences' administrator Silke Bernhard, who said she was overjoyed with the solution. The agreement provides for an independent budget for the conferences, supplied by the West Berlin Senate and various donors. Even in times of need, the university will not be able to cut the budget. In addition, the jobs of the conferences' several employees will be guaranteed under all circumstances.

Steven Dickman

\section{Cheery tone at SERC}

\section{London}

THE British Science and Engineering Research Council (SERC), the largest of the five research councils supporting work at British universities, seems deliberately to be seeking to lift the gloom over academic research in an up-beat review of activities up to the end of March this year.

Professor E. J. W. Mitchell, SERC's chairman, welcomes the British government's decision that spending this year and in the two following years should be increased by 1 per cent above previous estimates, saying that the result will be to relieve shortages that would otherwise have become plain in the provision of research grants, equipment and subscriptions to international agencies.

But Mitchell also says that the increasing cost of research must be acknowledged if the "seeds sown in the 1980 settlement are to germinate".

Mitchell's introduction includes an explicit commendation of the work of SERC's establishments, most of them founded to provide research facilities for general use by universities. The annual report notes that no country is able to pursue a rounded programme of research exclusively through universities and other academic institutions, and notes that by SERC's policy of allowing that 10 per cent of the cost of in-house research should be spent on basic research, the establishmets contribute the equivalent of 160 fulltime researchers to the British research enterprise.

This statement seems intended to counter criticisms that SERC spends too great a proportion of its resources on inhouse activities.

Of total expenditure in 1988-89 of $£ 365.5$ million (up by $£ 8$ million compared with the previous year), SERC spent $£ 123.6$ million on research grants (an increase of $£ 2$ million) and $£ 123$ million on providing grants for graduate students (an increase of $£ 1.5$ million). Subscriptions to international organizations such as CERN increased by $£ 3.5$ million to $£ 90.4$ million over the year, while spending at the council's own establishments and head office increased by $£ 3$ million to $£ 123.6$ million.

Over the year, spending on engineering research seems to have declined significantly (by more than 3 per cent to $£ 11$ million), but there seems to have been a healthy increase in the funds spent by the Science Board, which supports general research, from $£ 95.2$ million to $£ 104.7$ million, reflecting the general opinion that mainstream science has too often been short-changed in the pursuit of specialized programmes. 